\title{
Expression of matrix metalloproteinases (MMPs) and their inhibitor (TIMP) genes on mRNA and protein levels in oral squamous cell carcinoma
}

\author{
Artur Wróbel-Roztropiński , Bogna Zielińska-Kaźmierska', Hubert Roztropiński², \\ Weronika Lucas-Grzelczyk³, Janusz Szemraj ${ }^{4}$, Magdalena Józefowicz-Korczyńska ${ }^{3}$
}

\author{
'Maxillofacial Surgery Clinic, Medical University of Lodz, Lodz, Poland \\ ${ }^{2}$ Department of Dental Surgery, Medical University of Lodz, Lodz, Poland \\ ${ }^{3}$ Department of Otolaryngology and Oncological Laryngology, Medical University of Lodz, Lodz, Poland \\ ${ }^{4}$ Department of Medical Biochemistry, Medical University of Lodz, Lodz, Poland
}

Introduction. To investigate the mRNA and protein expression of MMP-2, MMP-9, MMP-7 and their tissue inhibitor TIMP-2 in tissue specimens with oral squamous cell cancer (OSCC) and in healthy tissues.

Material and methods. The expression genes of MMP-2, MMP-9, MMP-7 and TIMP-2 on mRNA levels were detected by the RT-PCR method in 31 samples with oral squamous cell carcinoma and in 31 healthy, control tissues. Secondly, the concentration of the analysed metalloproteinases and their inhibitor was assessed in tumor and non-tumor tissues using the enzyme-linked immunosorbent assay (ELISA) method.

Results. The mean values of gene expression of MMP-2, MMP-7, MMP-9 and TIMP in tissues with oral squamous cell cancer were significantly higher in comparison to normal ones $(p<0.0001)$. Similar observations were found for concentration levels of analysed MMPs and TIMP in tissues with and without oral cancer $(p<0.0001)$.

Conclusions. The present study demonstrated that MMP-2, MMP-7, MMP-9 and TIMP-2 gene expression on protein and mRNA levels is higher in oral squamous cell carcinoma tissues than in healthy control tissues. This may suggest that MMPs and TIMP play an important role in tumorogenesis. We did not observe any correlation between the clinicopathological characteristics of patients with OSCC and expression levels of MMPs and TIMP.

Key words: ELISA, enzyme assays, oral cancer, metalloprteinases

\section{Introduction}

According to the $\mathrm{WHO}$, the incidence of only oral cancers worldwide ranges from one to ten cases per 100000 , and the number of new cases grows every year [1]. A similar situation can be observed in Poland. According to the National Cancer Registry, oral cancers account for $4 \%$ of all cancer cases in men and $1 \%$ in women. In 2010, in Poland, the frequency of oral cavity and pharynx cancer in men was 1.4 times higher than the average for men in other EU countries (data from 2009), while in women this difference was smaller (about 1.2 times) [2]. In 2012, 1725 new cases of oral mucosal cancer were recorded [3]. In 2015, there was an increase by over 4000 new cases of malignant tumours in total. It should be mentioned that in the same year the Malignant Cancer Notification Card (KZNZ) was introduced for the first time, which would help with rapid diagnosis and oncological treatment, as well as improve the quality of statistical data [4].

\section{How to cite:}

Wróbel-Roztropiński A, Zielińska-Kaźmierska B, Roztropiński H, Lucas-Grzelczyk W, Szemraj J, Józefowicz-Korczyńska M. Expression of matrix metalloproteinases (MMPs) and their inhibitor (TIMP) genes on mRNA and protein levels in oral squamous cell carcinoma. NOWOTWORY J Oncol 2021; 71: 1-8. 
Despite the fact that the knowledge on prevention and treatment of oral cancer is increasing, the number of new cases increases every year, and treatment outcomes remains poor. New prognostic factors are being searched for, which could enable more precise determination of prognosis and selection of the optimal treatment methods required. Phases of head and neck carcinogenesis are now being widely investigated.

It was observed that the initiation of metastatic process depends on the ability of the primary oral squamous cell cancer (OSCC) to destroy/digest the extracellular matrix (ECM). This enables the penetration of tumor cells to the basement membrane (BM) and the initiation of angiogenesis [5-8]. Degradation of $\mathrm{BM}$, which is the first barrier inhibiting growth of the tumor, allows the invasion of the adjacent tissues and blood vessels. This process takes places in the pericellular environment and is a highly controlled cascade of events. Proteolytic enzymes are mainly responsible for these processes, among which metalloproteinases (MMPs) play a special role. MMPs calcium-dependent zinc-containing endopeptidases have various functions in the human organism. Twenty-five members of the MMP family have been identified $[9,10]$. Most of them are involved in common physiological processes like tissue regeneration and angiogenesis, morphogenesis, proliferation, differentiation and cells apoptosis [9-14].

It was discovered that stromal cells take part in the up-regulation of MMPs $[15,16]$. It has been assumed that the tumorogenesis of OSCC is possible due to the ability to utilise metalloproteinases produced by stromal cells of the host [16-18]. There is also a theory that cancer cells can stimulate their liberation [19].

The MMP family includes 25 different enzymes which have different functions. It appeared that MMP-2 and MMP-9 degrade collagen type IV which builds the BM, and MMP-7 degrades fibronectin, tenascin and $\beta 4$ integrin $[12,17,20-25]$.

A group of enzymes that are tissue inhibitors of metalloproteinases (TIMPs) have also been distinguished. Their role is to inhibit the activity of MMPs. The aim of this study was to investigate the mRNAs and protein expression of MMP-2, MMP9, MMP-7 and their tissue inhibitor TIMP-2 in tissue specimens with oral squamous cell cancer and in healthy tissues.

\section{Material and methods}

\section{Study group}

31 patients ( 3 women and 28 men) aged $60.6 \pm 7.3$ years were included in the study. Out of the 26 examined patients, 12 declared their rural origins and this group constitutes almost half of the total assessed patients. All of them were diagnosed with oral squamous cell carcinoma and underwent surgery at the Cranio-Maxillo-Facial and Oncological Department in the years 2015-2017. Patients enrolled in this research did not obtain any induction therapy. Tumor size and cancer staging were assessed according to the guidelines of the Union for
International Cancer Control (UICC) and the American Joint Committee on Cancer (AJCC) $[26,27]$. We also gathered information concerning lymph node metastates (negative - N0 versus positive - N1, N2, N3, N4) and smoking and alcohol habits. None of the patients had distant metastases at the date of inclusion in the study. The study group characteristics were presented in table I. This study was approved by the Ethics Committee (RNN/203/13/KE). The participant's informed consent was obtained verbally.

\section{Sample collection and preparation}

We gathered tissue fragments from cancerous lesions and from normal tumor adjacent tissue from all the patients enrolled in the study. Samples were preserved and stored at $-80^{\circ} \mathrm{C}$. Normal tissue was taken to be a control group. Control tissues were excised from a site distant by at least $2 \mathrm{~cm}$ from the macroscopic tumor border and confirmed as not having precancerous or cancerous lesions in the histopathological assessment. Tumor tissues were also histopathologically examined - oral squamous cell carcinoma was confirmed in all cases.

\section{RNA extraction and analysis}

From the frozen samples, RNA was extracted with the use of TRIZOL (Invitrogen Life Technologies) liquid - a liquid extraction technique with acid guanidinium thiocyanate-phenol-chloroform. The obtained RNA fragments were separated by an agarose gel electrophoresis. Only samples with well

Table I. Characterisation of patients with oral cancer $(n=31)$

\begin{tabular}{|c|c|c|}
\hline Variables & & No. of patients (\%) \\
\hline \multirow[t]{2}{*}{ sex } & female & $3(10)$ \\
\hline & male & $28(90)$ \\
\hline \multirow[t]{2}{*}{ age } & $<65$ & $23(74)$ \\
\hline & $>65$ & $8(26)$ \\
\hline \multirow[t]{4}{*}{ primary tumor size (T) } & $\mathrm{T} 1$ & $2(7)$ \\
\hline & $\mathrm{T} 2$ & $1(3)$ \\
\hline & T3 & $0(0)$ \\
\hline & T4 & $28(90) 5$ \\
\hline \multirow[t]{4}{*}{ nodal melostosen } & NO & $19(61)$ \\
\hline & N1 & $4(13)$ \\
\hline & N2 & $7(23)$ \\
\hline & N3 & $1(3)$ \\
\hline \multirow[t]{6}{*}{ clinical stage } & 1 & $2(7)$ \\
\hline & $\|$ & $1(3)$ \\
\hline & III & $0(0)$ \\
\hline & IVa & $27(87)$ \\
\hline & $\mathrm{IVb}$ & $0(0)$ \\
\hline & IVC & $1(3)$ \\
\hline \multirow[t]{3}{*}{ histopathological grading } & G1 & $1(3)$ \\
\hline & $\mathrm{G} 2$ & $25(81)$ \\
\hline & G3 & $5(16)$ \\
\hline
\end{tabular}


preserved ribosomal 28S, 18 S and 5S RNA were used in the study. Secondly, the RNA was digested with the DNAse I enzyme (GIBCO) for $15 \mathrm{~min}$. at room temperature. Five RNA of prepared ribonucleic acid were used for a reverse transcription reaction at $42^{\circ} \mathrm{C}$. for $60 \mathrm{~min}$, according to manufacturer protocol (ImProm-IITM Reverse Transcription System kit, Promega, USA). Obtained CDNA was then used in a real-time polymerase chain reaction (PCR) (Taq Mantm, Fast Start Universal Probe Master, ROX, Roche). In the real-time PCR, we used primers that were designed with the use of the Universal Probe Library.

Substrates for real-time PCR were performed in $50 \mu$ l final volume with $0.05 \mu \mathrm{g}$ of cDNA $25 \mu \mathrm{l}$ of Fast Start Universal Probe Master (ROX), $250 \mathrm{nM}$ probe and $1 \mu \mathrm{M}$ of each primer. PCR was carried out in a typical manner. Initialization consisted of heating the reaction chamber to a temperature of for 10 minutes to activate the Fast Start Taq DNA polymerase. Elongation included 40 rounds of $15 \mathrm{sec}$ each at $95^{\circ} \mathrm{C}$. Detection of amplification was performed with the use of an $\mathrm{ABI}$ Prism 7000 Sequence Detection System (Applied Biosystem). Each sample was tested in triplicate in independent reactions. The obtained real-time PCR data was automatically calculated with a special module using the $2^{-\Delta \Delta C t}$ method. Validation of PCR efficiency was performed. Serial dilution was done to prepare standard curves for each assessed gene.

\section{Determination of MMP-2, -7, -9, TIMP-2 levels using Enzyme-Linked Immunosorbent Assay (ELISA)}

The expression of the MMP-2, MMP-7, MMP-9 metalloproteinase proteins and their TIMP-2 inhibitor were assessed using a sandwich ELISA (enzyme-linked immunosorbent assay) from RayBiotech. The ELISA test was performed three times for each slice. Laboratory procedures were carried out in accordance with the manufacturer's instructions. The first step was to perform the coat stage, which was carried out by adding solid phase to the wells (where there were specific antibodies to human proteins MMP-2, MMP-7, MMP-9 and TIMP-2), tested samples (tissue homogonates) and control samples. After the incubation process, the plate is washed. Secondary antibodies labeled with horseradish peroxidase conjugated streptavidin, were then added. The wells were rinsed again. In the next step, a substrate (tetramethylbenzidine, TMB) was added for the enzyme (horseradish peroxidase) bound to the antibody; as a result of the enzymatic reaction this turns into a coloured product. Using spectrophotometry, the colour intensity was determined after a specified duration of reaction (Thermo Labsystem Multiskan Ascent 354), thanks to which the measurement of the antigen concentration in the material used for the tests was obtained.

\section{Statistical analysis}

For data distribution that differed significantly from normal distribution, non-parametric tests were applied. A Wilcoxon test for paired data and a Mann-Whitney $U$ test was used to determine the statistical significance of differences among the various analysed independent groups. In the case of covariates of interest, Spearman rank correlation coefficients were used. The $p<0.05$ was considered as a level of statistical significance. All the calculations were derived by means of Statistica v12.0 software.

Due to the retrospective nature of this study, it was granted an exemption in writing by the Medical University of Lodz IRB.

\section{Results}

\section{MMPs and TIMP mRNA expression}

Our study revealed that the mean values of gene expression of MMP-2, MMP-7, MMP-9 and TIMP in tissues with oral squamous cell cancer were significantly higher in comparison to normal ones $(p<0.0001)$. The detailed data was presented in table II.

We did not observe any relevant statistical correlation between the mRNA expression of analysed metaloproteinases and the clinicopathological features of patients with OSCC.

\section{Protein levels of MMPs and TIMP}

There was a significantly higher concentration of MMP-2, MMP-7, MMP-9 and TIMP in tissues with cancer than in control tissues $(p<0.0001)$, (tab. III).

No statistically significant correlation was noticed between protein levels of MMPs or TIMP analysed and the clinicopathological features of patients with OSCC like TNM advancement of tumor, clinical stage histopathological grading, smoking, patients' age and gender ( $p>0.05)$.

\section{Discussion}

Our study revealed that there was a higher expression of MMP-2, MMP-7, MMP-9 and TIMP mRNA in tissues with oral cancer than in normal tissues. We also observed that the

Table II. Comparison of mRNA level of selected genes ( $2^{-\Delta \Delta C t}$ expression) in tumor samples and tumor adjacent normal tissues

\begin{tabular}{|c|c|c|c|c|c|c|}
\hline & \multirow[t]{2}{*}{$n$} & \multicolumn{2}{|c|}{ Tumor } & \multicolumn{2}{|c|}{ Tumor adjacent normal tissues } & \multirow[t]{2}{*}{$\mathbf{p}$} \\
\hline & & mean & $\pm S D$ & mean & \pm SD & \\
\hline MMP-2 & 31 & 0.32 & $\pm \quad 0.10$ & 0.09 & \pm 0.03 & $<0.0001$ \\
\hline MMP-7 & 31 & 0.24 & $\pm \quad 0.07$ & 0.12 & \pm 0.04 & $<0.0001$ \\
\hline MMP-9 & 31 & 0.29 & $\pm \quad 0.15$ & 0.14 & \pm 0.04 & $<0.0001$ \\
\hline TIMP-2 & 31 & 0.26 & $\pm \quad 0.08$ & 0.12 & $\pm \quad 0.03$ & $<0.0001$ \\
\hline
\end{tabular}


MMP-2

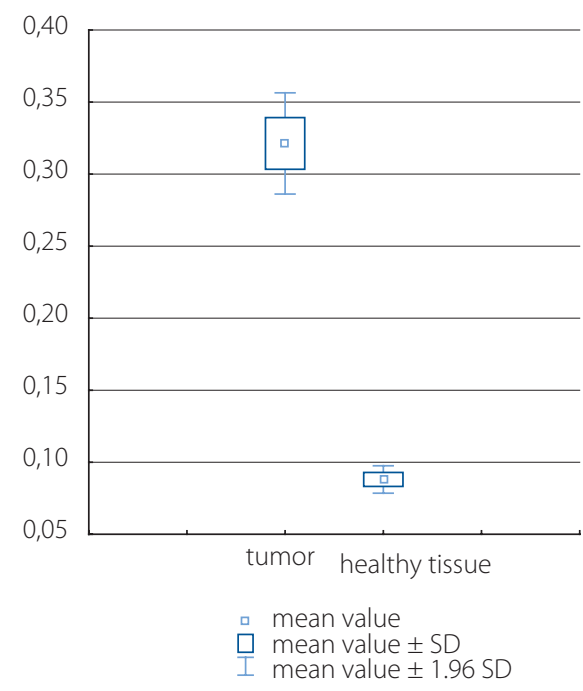

\section{MMP-9}

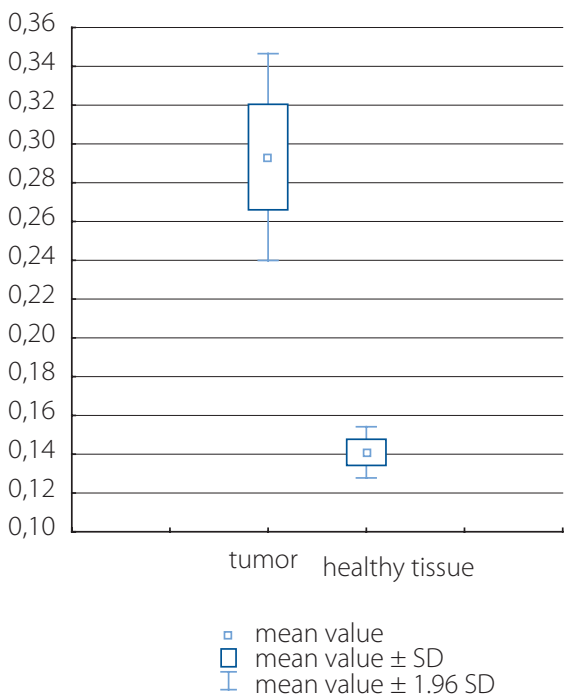

MMP-7

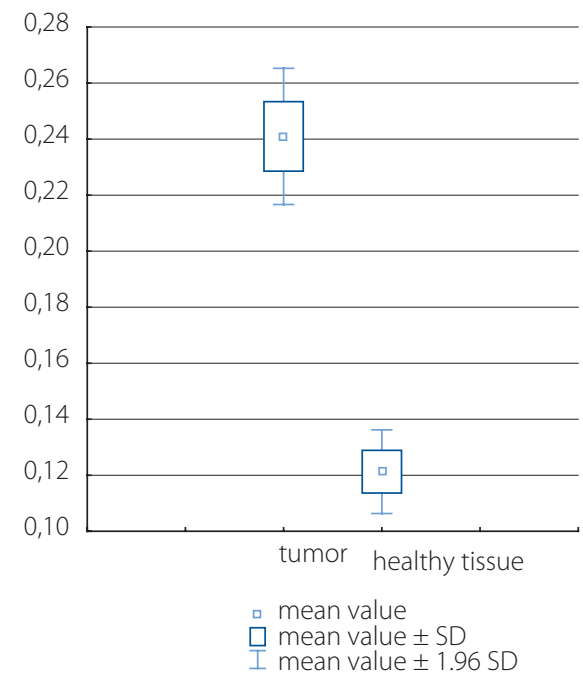

TIMP-2

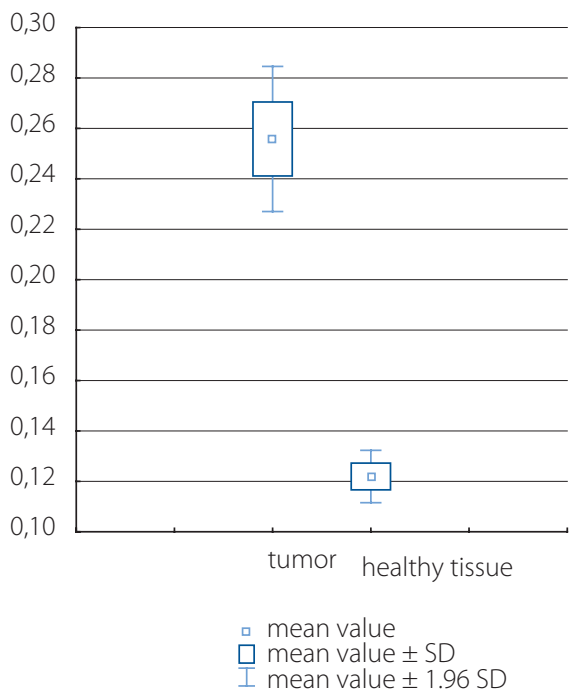

Figure 1. Comparison of mRNA level of selected genes in tumor sampels and tumor adjacent healthy tissue

Table III. Comparison of protein concentrations ( $\mathrm{ng} / \mathrm{ml}$ ) of MMP-2, MMP-7, MMP-9, TIMP-2 in tumor samples and tumor adjacent normal tissues

\begin{tabular}{|c|c|c|c|c|c|c|}
\hline & \multirow[t]{2}{*}{$n$} & \multicolumn{2}{|c|}{ Tumor } & \multicolumn{2}{|c|}{ Tumor adjacent normal tissues } & \multirow[t]{2}{*}{ p } \\
\hline & & mean & \pm SD & mean & $\pm \mathrm{SD}$ & \\
\hline MMP-2 & 31 & 941 & \pm 179 & 498 & \pm 102 & $<0.0001$ \\
\hline MMP-7 & 31 & 237 & \pm 45 & 144 & \pm 31 & $<0.0001$ \\
\hline MMP-9 & 31 & 319 & $\pm \quad 87$ & 172 & 33 & $<0.0001$ \\
\hline TIMP-2 & 31 & 138 & \pm 86 & 56 & 18 & $<0.0001^{*}$ \\
\hline
\end{tabular}

affected tissues had a significantly higher concentration of the analysed MMPs and their inhibitor. Many authors noticed similar results. The MMPs expression was found to be higher in neoplastic tissues from the head and neck region [28-30]. Higher protein concentration of MMP-2, MMP-7 and MMP-9 in head and neck cancers has also been reported by other authors [29]. Numerous studies have revealed a significantly increased level of the different MMPs expression and their inhibitors in head and neck cancers in comparison to healthy tissues [16-18, 20-25]. Most frequently, researchers investigate the potential role of MMP-2, MMP-3, MMP-8 and MMP-9 in tumorogenesis of oral squamous cell carcinoma 
MMP-2

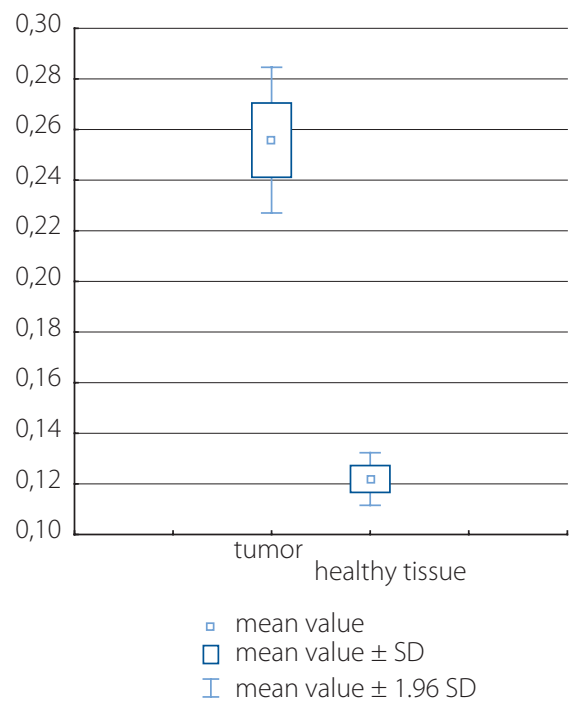

MMP-9

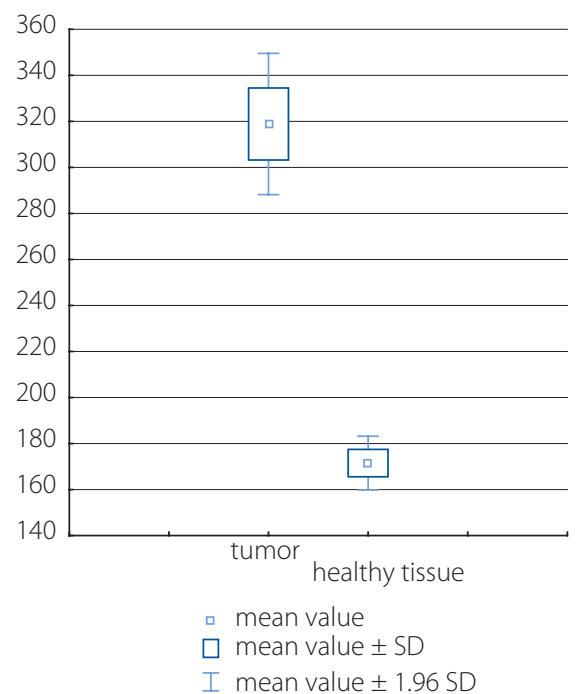

MMP-7

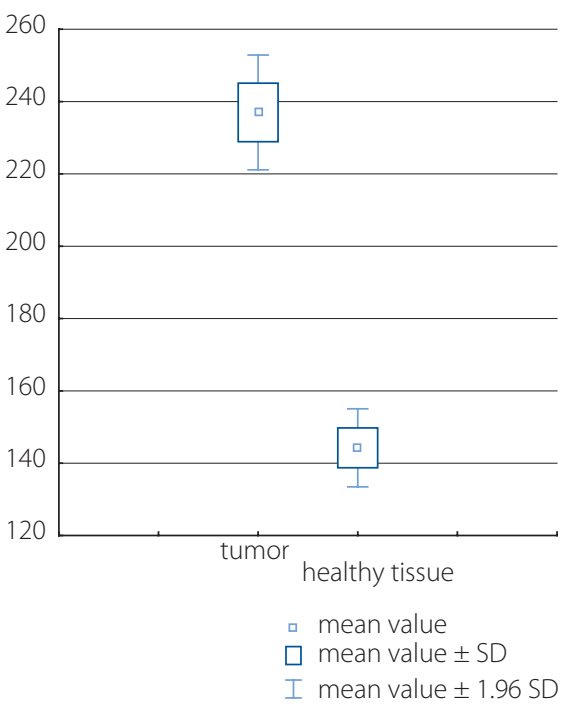

TIMP-2

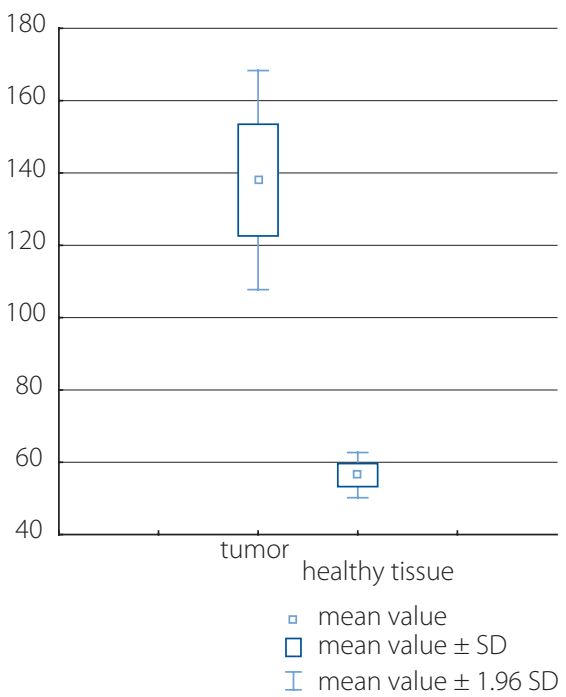

Figure 2. Comparison protein concentrations of MMP-2, MMP-7, MMP-9, TIMP-2 in tumor sampels and tumor adjacent healthy tissue

[28-31] Singh et al. investigated different combinations of MMPs and tissue inhibitors of MMPs for achieving better clinical efficacy [32].

In our study, we did not observe any significant correlation between either mRNA or the protein expression of MMP-2, MMP-7, MMP-9 and TIMP-2 and clinicopathological features like clinical stage, tumor size ( $\mathrm{T}$ ) and nodal status (N), as well as histopathological grading.

The major clinical problem in treating patients with oral cancers is local infiltration and the resulting destruction of critical structures, which is responsible for a majority of cancer related deaths, due to tumor involvement in critical organs [33]. Proteolytic degradation of ECM is an essential part of this process and different proteinases - including MMPs - have been proven to take part in it [34]. These observations prompted researchers to look for a relationship between gene expression of metalloproteinases and tumor progression. Thomas G.T. et al. and Kawamata $\mathrm{H}$. et al. presented the idea that gelatinases and their tissue inhibitors are not only over-expressed in tissues with oral squamous cell carcinoma, but are also related to tumor progression and invasion [18, 35]. A statistical correlation was observed between gelatinase mRNA, immunoreactive proteins or enzyme activity and clinical advancement of the OSCC-like tumor invasion or metastases to the lymph nodes $[17,36]$. Similar observations were made by Miyajima Y. et al. in hypopharyngeal squamous cell carcinoma [37]. On the other hand, there were also some reports that had results that were in accordance with ours. They proved a higher expression of MMPs in cancerous tissues but did not find any association between MMP protein expression and the stage or grade of 
Table IV. Characterisation of patients with laryngeal cancer $(n=96)$

\begin{tabular}{llc}
\hline Variables & & No. of patients (\%) \\
\hline sex & male & $3(10)$ \\
\hline age & $<65$ & $28(90)$ \\
\hline primary tumor size (T) & $>65$ & $23(74)$ \\
& T1 & $8(26)$ \\
\hline T2 & $2(7)$ \\
\hline T3 & $1(3)$ \\
\hline T4 & $0(0)$ \\
\hline nodal metastases & N0 & $28(90)$ \\
\hline N1 & $19(61)$ \\
\hline N2 & $4(13)$ \\
\hline N3 & $7(23)$ \\
\hline clinical stage & I & $1(3)$ \\
\hline II & $2(7)$ \\
\hline III & $1(3)$ \\
\hline IVa & $0(0)$ \\
\hline IVb & $27(87)$ \\
\hline IVc & $0(0)$ \\
\hline G1 & $1(3)$ \\
\hline & & $25(81)$ \\
\hline
\end{tabular}

the tumor [38]. Vicente J.C. et al. demonstrated over-expression of MMP-2 and MMP-9 and found a significant correlation between MMP-2 and MMP-9 and lymph node metastasis in patients with OSCC [39].

In the literature, there is a wide variety of results regarding MMPs, expression and their association with tumor staging in the head and neck region. The data on the correlation of the expression of metalloproteinases with invasion and nodal metastasis are inconclusive and the potential predictive role of MMPs and TIMPs in head and neck cancer progression and the influence on patients'treatment outcomes is still controversial. Several factors may contribute to this. First of all, there are different methodologies, as well as different antibodies, used in the analysed studies. Secondly, oral squamous cancer presents a heterogeneity of clinical features. Some authors failed to analyse TIMPs in association with MMPs, and it should be emphasised that the analysis of the interaction between the metalloproteinases and their inhibitors is more important than analysis of just one component [40].

\section{Conclusions}

The present study demonstrated that MMP-2, MMP-7, MMP-9 and TIMP-2 protein levels and mRNA expression is higher in oral squamous cell carcinoma tissues than in healthy control tissues. This may suggest that MMPs and TIMP play an important role in tumorogenesis. We did not observe any correlation between the clinicopathological characteristics of patients with OSCC and expression levels of MMPs and TIMP.
Conflict of interest: none declared

\author{
Artur Wróbel-Roztropiński \\ Medical University of Lodz \\ Maxillofacial Surgery Clinic \\ pl. Hallera 1 \\ 90-647 Lódź, Poland \\ e-mail:alakrawczyk3@gmail.com
}

Received: 2 May 2020

Accepted: 23 Jun 2020

\section{References}

1. http://www.who.int/oral_health/publications/cancer_maps/en/ (10.02.2018).

2. http://onkologia.org.pl/ (10.02.2018).

3. Zapała J, Wyszyńska-Pawelec G. Wybrane Zagadnienia z Onkologii Głowy i Szyi. Podręcznik dla lekarzy i studentów. Wydanie I. Wydawnictwo Uniwersytetu Jagiellońskiego, Kraków 2017.

4. Didkowska J, Wojciechowska U, Olasek P. Centrum Onkologii, Instytut im. M. Skłodowskiej-Curie. M Skłodowskiej-Curie, Warszawa 2017.

5. Aebersold DM, Beer KT, Laissue J, et al. Intratumoral microvessel density predicts local treatment failure of radically irradiated squamous cell cancer of the oropharynx. Int J Radiat Oncol Biol Phys. 2000; 48(1): 17-25, doi: 10.1016/s0360-3016(00)00573-3, indexed in Pubmed: 10924967.

6. Boon L, Ugarte-Berzal E, Vandooren J, et al. Glycosylation of matrix metalloproteases and tissue inhibitors: present state, challenges and opportunities. Biochem J. 2016; 473(11): 1471-1482, doi: 10.1042/ BJ20151154, indexed in Pubmed: 27234584.

7. Impola U, Cuccuru MA, Masala MV, et al. Preliminary communication matrix metalloproteinases in Kaposi's sarcoma. Br J Dermatol. 2003; 149(4): 905-907, doi: 10.1046/j.1365-2133.2003.05561.x, indexed in Pubmed: 14616400.

8. Impola U, Toriseva M, Suomela S, et al. Matrix metalloproteinase-19 is expressed by proliferating epithelium but disappears with neoplastic dedifferentiation. Int J Cancer. 2003; 103(6): 709-716, doi: 10.1002/ ijc.10902, indexed in Pubmed: 12516088.

9. Murray GI. Matrix metalloproteinases: a multifunctional group of molecules. J Pathol. 2001; 195(2): 135-137, doi: 10.1002/1096-9896(200109)195:2<135::AID-PATH939>3.0.CO;2-G, indexed in Pubmed: 11592090.

10. Jayade BV, Bhat $\mathrm{K}$, Patil BR, et al. Histological significance of $\mathrm{p} 53$ gene expression in squamous cell carcinoma of the buccal mucosa. J Maxillofac Oral Surg. 2009; 8(3): 205-210, doi: 10.1007/s12663-009-0051-6, indexed in Pubmed: 23139509.

11. Amar S, Smith L, Fields GB. Matrix metalloproteinase collagenolysis in health and disease. Biochim Biophys Acta Mol Cell Res. 2017; 1864(11 Pt A): 1940-1951, doi: 10.1016/j.bbamcr.2017.04.015, indexed in Pubmed: 28456643.

12. Luukkaa $M$, Vihinen $P$, Kronqvist $P$, et al. Association between high collagenase-3 expression levels and poor prognosis in patients with head and neck cancer. Head Neck. 2006; 28(3): 225-234, doi: 10.1002/ hed.20322, indexed in Pubmed: 16302191.

13. Mishev G, Deliverska E, Hlushchuk R, et al. Prognostic value of matrix metalloproteinases in oral squamous cell carcinoma. Biotechnol Biotechnol Equip. 2014; 28(6): 1138-1149, doi: 10.1080/13102818.2014.967510, indexed in Pubmed: 26019601.

14. Ranuncolo SM, Matos E, Loria D, et al. Circulating 92-kilodalton matrix metalloproteinase (MMP-9) activity is enhanced in the euglobulin plasma fraction of head and neck squamous cell carcinoma. Cancer. 2002; 94(5): 1483-1491, doi: 10.1002/cncr.10356, indexed in Pubmed: 11920505.

15. Basset $P$, Bellocq JP, Wolf $C$, et al. A novel metalloproteinase gene specifically expressed in stromal cells of breast carcinomas. Nature. 1990; 348(6303):699-704, doi: 10.1038/348699a0, indexed in Pubmed: 1701851.

16. Kato K, Hara A, Kuno T, et al. Matrix metalloproteinases 2 and 9 in oral squamous cell carcinomas: manifestation and localization of their activity. J Cancer Res Clin Oncol. 2005; 131(6): 340-346, doi: 10.1007/ s00432-004-0654-8, indexed in Pubmed: 15614523.

17. Kurahara S, Shinohara M, Ikebe T, et al. Expression of MMPS, MT-MMP, and TIMPs in squamous cell carcinoma of the oral cavity: correlations with tumor invasion and metastasis. Head Neck. 1999; 21(7): 627-638, 
doi: 10.1002/(sici)1097-0347(199910)21:7<627::aid-hed7>3.0.co;2-2, indexed in Pubmed: 10487950.

18. Thomas GT, Lewis MP, Speight PM. Matrix metalloproteinases and oral cancer. Oral Oncol. 1999; 35(3): 227-233, doi: 10.1016/s13688375(99)00004-4, indexed in Pubmed: 10621841.

19. Yorioka CW, Coletta RD, Alves F, et al. Matrix metalloproteinase-2 and -9 activities correlate with the disease-free survival of oral squamous cell carcinoma patients. Int J Oncol. 2002; 20(1): 189-194, indexed in Pubmed: 11743663

20. Rautava J, Luukkaa M, Heikinheimo K, et al. Squamous cell carcinomas arising from different types of oral epithelia differ in their tumor and patient characteristics and survival. Oral Oncol. 2007; 43(9): 911-919, doi: 10.1016/j.oraloncology.2006.11.012, indexed in Pubmed: 17257885.

21. Tang Yi, Nakada MT, Kesavan P, et al. Extracellular matrix metalloproteinase inducer stimulates tumor angiogenesis by elevating vascular endothelial cell growth factor and matrix metalloproteinases. Cancer Res. 2005; 65(8): 3193-3199, doi: 10.1158/0008-5472.CAN-04-3605, indexed in Pubmed: 15833850.

22. Imanishi Y, Fujii M, Tokumaru Y, et al. Clinical significance of expression of membrane type 1 matrix metalloproteinase and matrix metalloproteinase-2 in human head and neck squamous cell carcinoma. Hum Pathol. 2000; 31(8): 895-904, doi: 10.1053/hupa.2000.9756, indexed in Pubmed: 10987249.

23. Patel BP, Shah PM, Rawal UM, et al. Activation of MMP-2 and MMP-9 in patients with oral squamous cell carcinoma. J Surg Oncol. 2005; 90(2): 81-88, doi: 10.1002/jso.20240, indexed in Pubmed: 15844188.

24. Impola U, Jeskanen L, Ravanti L, et al. Expression of matrix metalloproteinase (MMP)-7 and MMP-13 and loss of MMP-19 and p16 are associated with malignant progression in chronic wounds. Br J Dermatol. 2005; 152(4): 720-726, doi: 10.1111/j.1365-2133.2005.06447.x, indexed in Pubmed: 15840104

25. Mimori K, Yamashita K, Ohta M, et al. Coexpression of matrix metalloproteinase-7 (MMP-7) and epidermal growth factor (EGF) receptor in colorectal cancer: an EGF receptor tyrosine kinase inhibitor is effective against MMP-7-expressing cancer cells. Clin Cancer Res. 2004; 10(24): 8243-8249, doi: 10.1158/1078-0432.CCR-04-0849, indexed in Pubmed: 15623600 .

26. American Joint Committee on Cancer: AJCC. www.cancerstaging.org (10.02.2018)

27. Union for International Cancer Control (UICC). www.uicc.org (10.02.2018)

28. Kapral M, Strzałka-Mrozik B, Paluch J, et al. Evaluation of gene expression of selected matrix metalloproteinases and their tissue inhibitors in laryngeal cancer. Farm Przegl Nauk. 2010; 10: 41-46.

29. Xie M, Sun Y, LiY. Expression of matrix metalloproteinases in supraglottic carcinoma and its clinical implication for estimating lymph node metastases. Laryngoscope. 2004; 114(12): 2243-2248, doi: 10.1097/01. mlg.0000149467.18822.59, indexed in Pubmed: 15564854.

30. Zhang H, Liu M, Sun Y, et al. MMP-14 can serve as a prognostic marker in patients with supraglottic cancer. Eur Arch Otorhinolaryngol. 2009; 266(9): 1427-1434, doi: 10.1007/s00405-009-0943-6, indexed in Pubmed: 19283401.

31. Grzelczyk WL, Wróbel-Roztropiński A, Szemraj J, et al. [The matrix metalloproteinase in oral and oropharyngeol cancer - literature review]. Postepy Biochem. 2016; 62(4): 506-510, indexed in Pubmed: 28132452.

32. Singh RD, Nilayangode $H$, Patel JB, et al. Combined evaluation of matrix metalloproteinases and their inhibitors has better clinical utility in oral cancer. Int J Biol Markers. 2011; 26(1): 27-36, doi: 10.5301/ jbm.2011.6359, indexed in Pubmed: 21337314.

33. Roomi MW, Monterrey JC, Kalinovsky T, et al. Patterns of MMP-2 and MMP-9 expression in human cancer cell lines. Oncol Rep. 2009; 21(5): 1323-1333, doi: 10.3892/or_00000358, indexed in Pubmed: 19360311.

34. Hong Qu, Jun T, Lei J, et al. Expression and Clinical Significance of Matrix Metalloproteinase-2 and Its Inhibitor TIMP-2 in Oral Squamous Cell Carcinoma. Journal of Hard Tissue Biology. 2006; 15(2): 54-60, doi: 10.2485/jhtb.15.54

35. Kawamata $\mathrm{H}$, Uchida $\mathrm{D}$, Hamano $\mathrm{H}$, et al. Active-MMP2 in cancer cell nests of oral cancer patients: correlation with lymph node metastasis. Int J Oncol. 1998; 13(4): 699-704, indexed in Pubmed: 9735398.

36. Ikebe $\mathrm{T}$, Shinohara $\mathrm{M}$, Takeuchi $\mathrm{H}$, et al. Gelatinolytic activity of matrix metalloproteinase in tumor tissues correlates with the invasiveness of oral cancer. Clin Exp Metastasis. 1999; 17(4): 315-323, doi: 10.1023/a:1006642428826, indexed in Pubmed: 10545018.

37. Miyajima $Y$, Nakano R, Morimatsu M. Analysis of expression of matrix metalloproteinases-2 and -9 in hypopharyngeal squamous cell carcinoma by in situ hybridization. Ann Otol Rhinol Laryngol. 1995;
104(9 Pt 1): 678-684, doi: 10.1177/000348949510400902, indexed in Pubmed: 7661515

38. Ruokolainen H, Pääkkö P, Turpeenniemi-Hujanen T. Expression of matrix metalloproteinase- 9 in head and neck squamous cell carcinoma: a potential marker for prognosis. Clin Cancer Res. 2004; 10(9):3110冈3116, doi: 10.1158/1078-0432.ccr-03-0530, indexed in Pubmed: 15131051.

39. de Vicente JC, Fresno MF, Villalain L, et al. Expression and clinical significance of matrix metalloproteinase- 2 and matrix metalloproteinase- 9 in oral squamous cell carcinoma. Oral Oncol. 2005; 41(3): 283-293, doi: 10.1016/j.oraloncology.2004.08.013, indexed in Pubmed: 15743691.

40. Overall CM, Kleifeld O. Tumour microenvironment - opinion: validating matrix metalloproteinases as drug targets and anti-targets for cancer therapy. Nat Rev Cancer. 2006; 6(3): 227-239, doi: 10.1038/nrc1821, indexed in Pubmed: 16498445.

41. Aebersold DM, Beer KT, Laissue J, et al. Intratumoral microvessel density predicts local treatment failure of radically irradiated squamous cell cancer of the oropharynx. Int J Radiat Oncol Biol Phys. 2000; 48(1): 17-25, doi: 10.1016/s0360-3016(00)00573-3, indexed in Pubmed: 10924967.

42. Boon L, Ugarte-Berzal E, Vandooren J, et al. Glycosylation of matrix metalloproteases and tissue inhibitors: present state, challenges and opportunities. Biochem J. 2016; 473(11): 1471-1482, doi: 10.1042/ BJ20151154, indexed in Pubmed: 27234584.

43. Impola U, Cuccuru MA, Masala MV, et al. Preliminary communication matrix metalloproteinases in Kaposi's sarcoma. Br J Dermatol. 2003; 149(4): 905-907, doi: 10.1046/j.1365-2133.2003.05561.x, indexed in Pubmed: 14616400.

44. Impola U, Toriseva M, Suomela S, et al. Matrix metalloproteinase-19 is expressed by proliferating epithelium but disappears with neoplastic dedifferentiation. Int J Cancer. 2003; 103(6): 709-716, doi: 10.1002/ ijc.10902, indexed in Pubmed: 12516088.

45. Murray GI. Matrix metalloproteinases: a multifunctional group of molecules. J Pathol. 2001; 195(2): 135-137, doi: 10.1002/1096-9896(200109)195:2<135::AID-PATH939>3.0.CO;2-G, indexed in Pubmed: 11592090.

46. Jayade BV, Bhat $\mathrm{K}$, Patil BR, et al. Histological significance of $\mathrm{p} 53$ gene expression in squamous cell carcinoma of the buccal mucosa. J Maxillofac Oral Surg. 2009; 8(3): 205-210, doi: 10.1007/s12663-009-0051-6, indexed in Pubmed: 23139509.

47. Amar S, Smith L, Fields GB. Matrix metalloproteinase collagenolysis in health and disease. Biochim Biophys Acta Mol Cell Res. 2017; 1864(11 Pt A): 1940-1951, doi: 10.1016/j.bbamcr.2017.04.015, indexed in Pubmed: 28456643.

48. Luukkaa $\mathrm{M}$, Vihinen $\mathrm{P}$, Kronqvist $\mathrm{P}$, et al. Association between high collagenase-3 expression levels and poor prognosis in patients with head and neck cancer. Head Neck. 2006; 28(3): 225-234, doi: 10.1002/ hed.20322, indexed in Pubmed: 16302191.

49. Mishev G, Deliverska E, HlushchukR, et al. Prognostic value of matrix metalloproteinases in oral squamous cell carcinoma. Biotechnol Biotechnol Equip. 2014; 28(6): 1138-1149, doi: 10.1080/13102818.2014.967510, indexed in Pubmed: 26019601.

50. Ranuncolo SM, Matos E, Loria D, et al. Circulating 92-kilodalton matrix metalloproteinase (MMP-9) activity is enhanced in the euglobulin plasma fraction of head and neck squamous cell carcinoma. Cancer. 2002; 94(5): 1483-1491, doi: 10.1002/cncr.10356, indexed in Pubmed: 11920505.

51. Basset P, Bellocq JP,WolfC, et al. A novel metalloproteinase gene specifically expressed in stromal cells of breast carcinomas. Nature. 1990; 348(6303): 699-704, doi: 10.1038/348699a0, indexed in Pubmed: 1701851

52. Kato K, Hara A, Kuno T, et al. Matrix metalloproteinases 2 and 9 in oral squamous cell carcinomas: manifestation and localization of their activity. J Cancer Res Clin Oncol. 2005; 131(6): 340-346, doi: 10.1007/ s00432-004-0654-8, indexed in Pubmed: 15614523.

53. Kurahara S, Shinohara M, Ikebe T, et al. Expression of MMPS, MT-MMP and TIMPs in squamous cell carcinoma of the oral cavity: correlations with tumor invasion and metastasis. Head Neck. 1999; 21(7): 627-638, doi: 10.1002/(sici)1097-0347(199910)21:7<627::aid-hed7>3.0.co;2-2, indexed in Pubmed: 10487950.

54. Thomas GT, Lewis MP, Speight PM. Matrix metalloproteinases and oral cancer. Oral Oncol. 1999; 35(3): 227-233, doi: 10.1016/s13688375(99)00004-4, indexed in Pubmed: 10621841.

55. Yorioka CW, Coletta RD, Alves F, et al. Matrix metalloproteinase-2 and -9 activities correlate with the disease-free survival of oral squamous cell carcinoma patients. Int J Oncol. 2002; 20(1): 189-194, indexed in Pubmed: 11743663.

56. Rautava J, Luukkaa M, Heikinheimo K, et al. Squamous cell carcinomas arising from different types of oral epithelia differ in their tumor and pa- 
tient characteristics and survival. Oral Oncol. 2007; 43(9): 911-919, doi: 10.1016/j.oraloncology.2006.11.012, indexed in Pubmed: 17257885.

57. Tang Yi, Nakada MT, Kesavan P, et al. Extracellular matrix metalloproteinase inducer stimulates tumor angiogenesis by elevating vascular endothelial cell growth factor and matrix metalloproteinases. Cancer Res. 2005; 65(8): 3193-3199, doi: 10.1158/0008-5472.CAN-04-3605, indexed in Pubmed: 15833850.

58. Imanishi Y, Fujii M, Tokumaru Y, et al. Clinical significance of expression of membrane type 1 matrix metalloproteinase and matrix metalloproteinase-2 in human head and neck squamous cell carcinoma. Hum Pathol. 2000; 31(8): 895-904, doi: 10.1053/hupa.2000.9756, indexed in Pubmed: 10987249.

59. Patel BP, Shah PM, Rawal UM, et al. Activation of MMP-2 and MMP-9 in patients with oral squamous cell carcinoma. J Surg Oncol. 2005; 90(2): 81-88, doi: 10.1002/jso.20240, indexed in Pubmed: 15844188

60. Impola U, Jeskanen L, Ravanti L, et al. Expression of matrix metalloproteinase (MMP)-7 and MMP-13 and loss of MMP-19 and p16 are associated with malignant progression in chronic wounds. Br J Dermatol. 2005; 152(4): 720-726, doi: 10.1111/j.1365-2133.2005.06447.x, indexed in Pubmed: 15840104

61. Mimori K, Yamashita K, Ohta M, et al. Coexpression of matrix metalloproteinase-7 (MMP-7) and epidermal growth factor (EGF) receptor in colorectal cancer: an EGF receptor tyrosine kinase inhibitor is effective against MMP-7-expressing cancer cells. Clin Cancer Res. 2004; 10(24): 8243-8249, doi: 10.1158/1078-0432.CCR-04-0849, indexed in Pubmed: 15623600.

62. American Joint Committee on Cancer: AJCC. www.cancerstaging.org (10.02.2018).

63. Union for International Cancer Control (UICC). www.uicc.org (10.02.2018)

64. Kapral M, Strzałka-Mrozik B, Paluch J, et al. Evaluation of gene expression of selected matrix metalloproteinases and their tissue inhibitors in laryngeal cancer. Farm Przegl Nauk. 2010; 10: 41-46.

65. Xie M, Sun Y, LiY. Expression of matrix metalloproteinases in supraglottic carcinoma and its clinical implication for estimating lymph node metastases. Laryngoscope. 2004; 114(12): 2243-2248, doi: 10.1097/01. mlg.0000149467.18822.59, indexed in Pubmed: 15564854.

66. Zhang H, Liu M, Sun Y, et al. MMP-14 can serve as a prognostic marker in patients with supraglottic cancer. Eur Arch Otorhinolaryngol. 2009;
266(9): 1427-1434, doi: 10.1007/s00405-009-0943-6, indexed in Pubmed: 19283401

67. Grzelczyk WL, Wróbel-Roztropiński A, Szemraj J, et al. [The matrix metalloproteinase in oral and oropharyngeol cancer - literature review]. Postepy Biochem. 2016; 62(4): 506-510, indexed in Pubmed: 28132452

68. Singh RD, Nilayangode $\mathrm{H}$, Patel JB, et al. Combined evaluation of matrix metalloproteinases and their inhibitors has better clinical utility in oral cancer. Int J Biol Markers. 2011; 26(1): 27-36, doi: 10.5301/ jbm.2011.6359, indexed in Pubmed: 21337314.

69. Roomi MW, Monterrey JC, Kalinovsky T, et al. Patterns of MMP-2 and MMP-9 expression in human cancer cell lines. Oncol Rep. 2009; 21(5): 1323-1333, doi: 10.3892/or_00000358, indexed in Pubmed: 19360311.

70. Hong Qu, Jun T, Lei J, et al. Expression and Clinical Significance of Matrix Metalloproteinase-2 and Its Inhibitor TIMP-2 in Oral Squamous Cell Carcinoma. J Hard Tissue Biol. 2006; 15(2): 54-60, doi: 10.2485/jhtb.15.54.

71. Kawamata $\mathrm{H}$, Uchida $\mathrm{D}$, Hamano $\mathrm{H}$, et al. Active-MMP2 in cancer cell nests of oral cancer patients: correlation with lymph node metastasis. Int J Oncol. 1998; 13(4): 699-704, indexed in Pubmed: 9735398.

72. Ikebe T, Shinohara M, Takeuchi $\mathrm{H}$, et al. Gelatinolytic activity of matrix metalloproteinase in tumor tissues correlates with the invasiveness of oral cancer. Clin Exp Metastasis. 1999; 17(4): 315-323, doi: 10.1023/a:1006642428826, indexed in Pubmed: 10545018

73. Miyajima $Y$, Nakano R, Morimatsu M. Analysis of expression of matrix metalloproteinases- 2 and -9 in hypopharyngeal squamous cell carcinoma by in situ hybridization. Ann Otol Rhinol Laryngol. 1995; 104(9 Pt 1): 678-684, doi: 10.1177/000348949510400902, indexed in Pubmed: 7661515.

74. Ruokolainen H, Pääkkö P, Turpeenniemi-Hujanen T. Expression of matrix metalloproteinase-9 in head and neck squamous cell carcinoma: a potential marker for prognosis. Clin Cancer Res. 2004; 10(9): 3110-3116, doi: 10.1158/1078-0432.ccr-03-0530, indexed in Pubmed: 15131051.

75. de Vicente JC, Fresno MF, Villalain L, et al. Expression and clinical significance of matrix metalloproteinase- 2 and matrix metalloproteinase- 9 in oral squamous cell carcinoma. Oral Oncol. 2005; 41(3): 283-293, doi: 10.1016/j.oraloncology.2004.08.013, indexed in Pubmed: 15743691.

76. Overall CM, Kleifeld O.Tumour microenvironment - opinion: validating matrix metalloproteinases as drug targets and anti-targets for cancer therapy. Nat Rev Cancer. 2006; 6(3): 227-239, doi: 10.1038/nrc1821, indexed in Pubmed: 16498445. 